\section{CRIPPLED CHILDREN'S CHRISTMAS.}

\section{To the Editors of THE LANorrs.}

SIRs,-By a rote of the Court of Common Council to-day the Corporation of the City of London has for the fourth time granted the use of the Guildhall for the Christmas entertainment to ragged school children which it has been my privilege annually to promote. The guests are drawn from all of the poorest parts of the metropolis. I am sure that the sight of their radiant faces at the well-spread board under the eye of those genial giants-Gog and Magog-must have repaid the kind-hearted donors of this joyful feast. I have every confidence that the generous public will once more assist as liberally as heretofore, but this year I ask for your coöperation to make a special and wider appeal.

There are over 5000 little crippled children passing a monotonous existence in crowded courts and alleys in this great city. Many of them are stretched on beds of suffering and are prisoners from year's end to year's end. Others are quite unable to participate in the pleasures offered to the more robust. Realising how sad was the lot of these aflicted little ones last year the surplus of the funds entrusted to me for the children's banquet at the Guildhall was spent in providing 100 Christmas hampers for crippled children. There was not the smallest difficulty in distributing them to the most deserving cases, for every cripple is registered and visited systematically by the Ragged School Union. But in making the selections it gave great pain to be obliged to refuse four out of every five applicants. Why should not all the 5000 homes be brightened and made happy for one day at least in the year?

It rests simply with sympathetic people to provide the means. The cripples' Christmas hamper may be large or small according to the measure of support I may receive. Last year it contained a $2 \mathrm{lb}$. meat pie, a plum-pudding, a substantial cake, a packet of tea, and a parcel of sweets; and judging from the pathetic letters of thanks these unaccustomed dainties-the mere elements of Christmas faregave untold satisfaction. That is why I want to disappoint no child-cripple this year out of the 5000 and that is the reason why I would earnestly ask for contributions, large or small, to be sent to the Little Cripples' Christmas Frand, care of Alderman Treloar, Ludgate-hill, E.C.

I am, Sirs, your obedient servant,

Ludgate-hill, Nov. 18th.

W. P. TRELOAR.

\section{"DR. RENTOUL'S CLAIM FOR FEES FROM} THE MEDICAL COUNCIL."

\section{To the Editors of THW LANOHT.}

Srks,-In your issue of Dec. 4th, under your report of the November session of the Medical Council, reference is made to a claim made by me for a fee of $\$ 1010 \mathrm{~s}$. $0 \mathrm{~d}$. from the Medical Council. My claim rests upon the following Standing Order of the Medical Council:-Section XI. 4: " Each member of the General Conncil who resides more than two hundred miles from London shall receive five guineas for the day of his coming and five guineas for the day of his return." In so far as I can find out, the Treasurers of the Medical Council (Sir D. Duckworth and Mr. Bryant) object to pay me the 10 guineas for the three following reasons :-

1st. That Mr. M. Banks, when on the Meüical Council, did not receive any payment under the above Rule. From what I have learned, I believe Dr. Banks did not know of this Rule. Had he known, I feel fairly certain he would have claimed. But I have stated tinat I refuse absolutely to be bound by what one member of the Medical Council has done. The above rule was made-not by one member of the Medical Council, but by the majority, of the Council, and in 1859. Let me project this excuse for non-payment a little further so as to see how ludicrously ridiculous it is. Suppose Dr. Banks had refused to take any payment whatsoever. Such an action of his could, according to the Treasurers, be used against me, or any other member, just as the above has been! Wither the above rule is, or is not in force. If it be still in force, let it be honestly put into force. If not, let it be struck out.

2ad. Wil D. Bxekworth and Mr. Bryant contend that the above Rule does not take in the distance from my residence to the Medical Council office. I contend that it does. The word " resides" is expressly and pointedly used in the above Rule. Do they contend that I" reside" at the railway station! The distance from my residence to the Medical Council is 2044 miles. I contend that under the term "resides" is included the total distance travelled by a member attending a meeting of the Medical Conncil. It can not include railway travelling only. Else how could the Irish Representatives, when travelling by boat, be justly dealt with. Again, supposing a Member has to drive 5 to 10 miles, is this distance not to be included when making up the total 200 miles?

3rd. Sir D. Duckworth and Mr. Bryant wrongly calculate the distance to London upon the charges made by the Railway companies from their third class parliamentary fare. No method of calculating is more absurd. In my letter of Jaly 13th, '97, I particularly pointed out that the railway fare charged was not based upon the distance, but was due to the prices charged for tickets by the competing railway companies. In his letter to me of June 16th he says-" the Parliamentary fare to Liverpool, 16s. 6d., is calculated on the basis of the distance being 198 miles." This is a very gross and grave inaccuracy, and especially so when made by Teasurers of the funds of the Council. There are three chief railway lines from Liverpool to London: the L. \& N. Western; the Midland; and the Great Western. The distance from station to station (Liverpool to London), by the L. \& N. W. is 201 miles; by the Midland, over 218 miles; and by the Gt. Western 228 miles. By Section 6 of the Cheap Trains Act, 1844, it is enacted that the Parliamentary fare shall not 'exceed' one penny for each mile. But, be it noted, this act does not say the railway companies shall not charge under one penny per mile. Evidently Sir D. Duckworth and Mr. Bryant fancy the railway companies charge just as high a price as they legally can. But this is not so. Competition among railway companies steps in as among other affairs of life. If the railway companies charged up to their legal rates, the Gt. Western with its 228 miles, at $1 d$. per mile, would charge $17 s$. $8 d$. (it actually, with the longest distance of the three, charges $16 s .2 \frac{1}{2} d .:$ the Midland, with its over 218 miles could charge 18s. $0 \frac{1}{2} d$. (it actually charges 16s. 6d.): while the L. \& N. Western with its 201 miles could charge 16s. 9d. (it actually charges 16s. 6d.). Therefore, by the shortest distance from station to station (upon the chief objection of Sir D. Duckworth and Mr. Bryant) is 201 miles. This being so, and taking it that the above Rule refers only to the distance from station to station $I$ can honestly claim the above fee of $£ 1010 \mathrm{~s}$.

All the above facts were laid by me before Sir D. Duckworth and Mr. Bryant in my letters of June 14th and July 13th, '97. Let me just add, I believe this pettifogging action of these two gentlemen would not have taken place had I not, at the last May session of the Medical Council, stated, when the subject of Medical Aid Associations was before the Council, that if the Council was to act honestly in this matter, it must wash its own hands first, as at least one Member of the Council was connected with a London hospital (Guy's) which was to all practical purposes a large medical aid association at which persons, by paying threepence per week, or sixpence per fortnight, could obtain outpatient medical and surgical treatment and medicines; the medical officers being specially paid about $£ 100$ per annum each for such services; and where beds for in-patients were advertised at from 21s. to $63 \mathrm{~s}$. per week. If this statement is false, then I publicly challenge the members of the Medical Council connected with this "hospital" (or medical aid association) to deny it.

There are two other statements made by Sir D. Duckworth and reported to which I wish to refer. He stated before the Council that I asked him if I was to be paid for my wife's presence in London. I can only answer this gross impertinence by publicly stating that the person who said it is a gross perjurer of the truth. Is it likely that I would make such a claim, or if I thought I could make it would I not first have read the rules of the Council or asked the Registrar privately? Evidently the raantle of knighthood sometimes covers those who are not above using the grossest slander. I have been " blackballed" by the members of the Liverpool Medical Institute for memabership on acconnt of the action $I$ have taken upon the question of abuse of medical charities. This $I$ dn ct much mind. But if Sir $D$. Duckworth insists in drag $\mathrm{ng}$ in oth rs clusely related to me I shall take a very : arp method of try ng to teach him how to act as a gentleman. His o her gross y untrue statement is "that Dr. Rentoul lad got the Chief Constable of Liverpool 